\author{
MAŁGORZATA MAJDER-ŁOPATKA ${ }^{1}$, WIESŁAW SZULC*2, BEATA RUTKOWSKA ${ }^{2}$, \\ DOMINIK PTASIŃSKI ${ }^{2}$, WITOLD KAZBERUK ${ }^{2}$ \\ ${ }^{1}$ The Main School of Fire Service, Department of Fire Safety Engineering \\ 52/54 Stowackiego Str., 01-629 Warsaw, Poland \\ ${ }^{2}$ Warsaw University of Life Sciences, Faculty of Agriculture and Biology, Department of Soil Environment Sciences \\ 159 Nowoursynowska Str., building 37, 02-776 Warsaw, Poland
}

\title{
Influence of fire on selected physico-chemical properties of forest soil
}

\begin{abstract}
The aim of the research was to determine whether, and to what extent, a surface fire of forest areas determines changes in physical and chemical properties of the soil. The test material consisted of soil samples taken from soil profiles exposed in a burntout area and in an area unaffected by fire. The samples were analyzed for total organic carbon and total nitrogen contents, and also selected indicators of soil acidification. As a result of the tests, it was found that there was a decrease in the levels of organic carbon (by over $75 \%$ ) and nitrogen (by $50 \%$ ). A negative effect of the changes was the narrowing of the $\mathrm{C} / \mathrm{N}$ ratio, a positive one - an increase in soil $\mathrm{pH}$ (from 3.14 to 4.67 ), and a several-times reduction in hydrolytic and exchangeable acidity.
\end{abstract}

Keywords: fire, forest, soil properties

\section{INTRODUCTION}

In the European Union, Poland is counted among the countries with medium risk of forest fires. According to the data of the Joint Research Centre in Ispra, it ranks third (behind Portugal and Spain) in terms of the average annual number of fires, but in eighth place when taking into account the area covered by them (website 1).

The high forest fire risk in Poland is due to, among other things, the fact that Polish forests are among the most combustible areas in Central Europe. It is the result of a high proportion of coniferous forest habitats and pine dominance in the species composition, as well as the age of tree stands. According to the General Directorate of State Forests, forests up to the age of 40 years are the most flammable, constituting nearly $29 \%$ of the forested area of the country. The forests are located on the poorest soils (podzols, podzolic and rusty soils) with a low organic matter content and drying out quickly (website 2). The majority (about 95\%) of forest fires in Poland are embryonic fires (up to 0.05 ha) and small fires (up to $1 \mathrm{ha}$ ) (Szczygieł 2012). Forest fires occur throughout the year, but the highest incidence of them is observed from April to September, especially during prolonged periods with high temperatures, low humidity, and strong winds (Sawicki 2004, Ubysz and Szczygieł 2005). In 2011, almost 70\% of forest fires broke out in the April-June period (Szczygieł and Piwnicki 2012).
According to Szczygiel (2012), the number of fires in Polish forests is systematically increasing from 1.5-2 thousand. in the first half of the twentieth century, over 10,000 In recent years. In the literature on the subject, there are few reports on forest fires and their impact on the habitat in light soils typical of Poland (Hewelke et al. 2018, Bojarski and Kaczmarek 2018; Bartkowiak and Lemanowicz 2017).

The forest fires occurring in Poland are predominantly low-temperature fires, in which the top layer of soil reaches a temperature of $200^{\circ} \mathrm{C}-300^{\circ} \mathrm{C}$ (Prędecka 2009). For the normal functioning of forest ecosystems, the temperature of soil surface horizons, in which all biological life is concentrated, is very important. Therefore, even lower temperatures, not exceeding $100^{\circ} \mathrm{C}$, can cause severe damage for environment. The first signs of organic matter decomposition appear already at $50^{\circ} \mathrm{C}$. Indirectly, through damage or destruction of soil organic matter, the physical and chemical properties of forest soils undergo a change. As a result, such soils are characterized by a negative water balance, total porosity is reduced, and the organic matter begins to acquire hydrophobic properties (Hubbert et al. 2012). As a result of surface fires, the ecosystem is enriched with nutrients contained in ashes from burnt plants. Value of soil $\mathrm{pH}$ increases and so does the availability of $\mathrm{P}$, $\mathrm{K}, \mathrm{Mg}$ and $\mathrm{Ca}$. Fires also lead to the impoverishment of ecosystems because they become depleted of nutrients such as $\mathrm{N}$ and $\mathrm{S}$, which move to the atmosphere in a gaseous form or with the smoke in 
the form of dust particles of organic matter. The cation exchange capacity is also reduced and the degree of saturation of the sorption complex with basic cations increases. The greatest intensity of these changes in forest ecosystems occurs immediately after a fire, but they are also recorded after several or even more than a dozen years (Gonet 2010).

The aim of the research was to determine whether, and to what extent, a forest fire determines changes in physico-chemical properties of forest soils.

\section{MATERIALS AND METHODS}

The study was conducted in a burnt forest area near the village of Sieraków, Laski Forest District, central Poland, Masovia Voivodeship (E 20 51' 19", $\left.\mathrm{N} 52^{\circ} 19^{\prime} 5^{\prime \prime}\right)$ (Table 1). The burnt-out site covered an area of 1.2 ha.

The soil in study area was a Podzol overgrown with 61-year-old Scots pine and the habitat was classified as fresh mixed coniferous forest (BMśw in Polish classification). Soil profiles were made in a place covered by fire as well as in the control area not covered by a fire. Soil samples were taken from all genetic levels on three terms. The first sampling

TABLE 1. Morphological properties of the Podzol soil on the test surface - Sieraków

\begin{tabular}{llll}
\hline $\begin{array}{l}\text { Burnt area } \\
\begin{array}{l}\text { Genetic } \\
\text { horizon }\end{array}\end{array}$ & $\begin{array}{l}\text { Depth } \\
{[\mathrm{cm}]}\end{array}$ & $\begin{array}{l}\text { Control } \\
\text { horizon }\end{array}$ & $\begin{array}{l}\text { Depth } \\
{[\mathrm{cm}]}\end{array}$ \\
\hline Oh & $2-0$ & Oi & $4-3$ \\
\hline AEs & $0-16$ & Oe & $3-0$ \\
\hline Bhs & $16-40$ & AEs & $0-16$ \\
\hline BhsC & $40-80$ & Bhs & $16-35$ \\
\hline C & $>80$ & BhSC & $35-60$ \\
\hline & & C & $>60$ \\
\hline
\end{tabular}

Soils were described and classified according to WRB soil classification (IUSS Working Group WRB 2015). date was immediately after the fire (term 1), the second half a year later (term 2), and the third a year after the fire (term 3 ). The collected soil samples were dried until the moisture content had reached the level of air humidity. They were then sieved through a $2 \mathrm{~mm}$ sieve. Chemical analyses of soil samples included: determination of: $\mathrm{pH}$ in $1 \mathrm{~mol} \cdot \mathrm{dm}^{-3} \mathrm{KCl}$ solution by the potentiometric method using a Schott $\mathrm{pH}$ meter, hydrolytic acidity $(\mathrm{Hh})$ according to Kappen's method, exchangeable acidity (Hex) according to Sokolov method and exchangeable aluminium (Alex) content after extraction in $1 \mathrm{~mol} \cdot \mathrm{dm}^{-3} \mathrm{KCl}$ solution by atomic emission spectrometry method (ICP-AES) (IRYS Advantage ThermoElementar), total nitrogen (TN) according to Kjeldaha method using a Gerhardt nitrogen analyzer, total organic carbon (TOC) content with a PC controlled Eltra CS 530 Carbon / Sulfur Analyzer.

\section{RESULTS AND DISCUSSION}

During a forest fire, a significant amount of organic matter undergoes sudden mineralization, as a result of which the content of macro- and microelements in the soil changes. The elements in organic compounds, such as nitrogen and carbon, may be converted into volatile products (Borman et al. 2008, Caldwell et al. 2002, Gonet 2010). In the test areas unaffected by fire (Table 2), the concentration of organic carbon in the Oe horizon ranged from 260.3 to $280.1 \mathrm{~g} \cdot \mathrm{kg}^{-1}$, whereas that of the total nitrogen from 10.9 to $13.3 \mathrm{~g} \cdot \mathrm{kg}^{-1}$. The obtained values are consistent with the literature data presented by many authors (Januszek et al. 2001, Badia et al. 2017, Alcañiz et al. 2016). The fire significantly reduced the organic carbon and total nitrogen contents in the organic horizon of the soil (Table 3).

Immediately after the fire, the organic carbon content in the burnt horizon was $70.9 \mathrm{~g} \cdot \mathrm{kg}^{-1}$, which was approx. $27 \%$ of the value obtained in the sample taken nearby, from a place unaffected by the fire.

TABLE 2. Organic carbon and total nitrogen contents $\left(\mathrm{g} \cdot \mathrm{kg}^{-1}\right)$, and $\mathrm{C} / \mathrm{N}$ ratio in the Podzol soil from the village of Sieraków - area unaffected by fire

\begin{tabular}{lccccccccccc}
\hline \multirow{2}{*}{ Horizon } & \multirow{2}{*}{$\mathrm{cm}$} & \multicolumn{1}{c}{ Term 1} & \multicolumn{3}{c}{ Term 2} & \multicolumn{3}{c}{ Term 3 } \\
\cline { 2 - 12 } & & TOC & TN & C/N & TOC & TN & C/N & TOC & TN & C/N \\
\hline Oi & $4-3$ & 265.5 & 13.3 & 19.9 & 260.3 & 10.9 & 23.9 & 280.1 & 12.2 & 23.0 \\
\hline Oe & $3-0$ & 32.4 & 1.4 & 23.2 & 23.1 & 0.9 & 25.7 & 13.0 & 0.5 & 26.0 \\
\hline AEs & $0-16$ & 9.3 & 0.5 & 18.6 & 7.0 & 0.3 & 23.3 & 9.1 & 0.4 & 22.7 \\
\hline Bhs & $16-35$ & 5.2 & 0.3 & 17.2 & 3.9 & 0.2 & 19.5 & 4.5 & 0.3 & 15.1 \\
\hline BhsC & $35-60$ & 1.6 & 0.2 & 8.2 & 0.7 & 0.1 & 7.3 & 1.3 & 0.2 & 6.3 \\
\hline C & $>60$ & 0.6 & 0.1 & 5.9 & 0.5 & 0.1 & 4.9 & 1.0 & 0.2 & 4.9 \\
\hline
\end{tabular}


TABLE 3. Organic carbon and total nitrogen contents $\left(\mathrm{g} \cdot \mathrm{kg}^{-1}\right)$, and $\mathrm{C} / \mathrm{N}$ ratio in the Podzol soil from the village of Sieraków - area affected by fire

\begin{tabular}{|c|c|c|c|c|c|c|c|c|c|c|}
\hline \multirow[t]{2}{*}{ Horizon } & \multirow[t]{2}{*}{$\mathrm{cm}$} & \multicolumn{3}{|c|}{ Term 1} & \multicolumn{3}{|c|}{ Term 2} & \multicolumn{3}{|c|}{ Term 3} \\
\hline & & TOC & TN & $\mathrm{C} / \mathrm{N}$ & TOC & $\mathrm{TN}$ & $\mathrm{C} / \mathrm{N}$ & $\mathrm{TOC}$ & $\mathrm{TN}$ & $\mathrm{C} / \mathrm{N}$ \\
\hline $\mathrm{Oh}$ & $2-0$ & 70.9 & 6.7 & 10.6 & 64.8 & 5.4 & 12 & 109.5 & 7.4 & 14.8 \\
\hline \multirow[t]{2}{*}{ AEs } & $0-8$ & 14.2 & 0.6 & 23.7 & 14.8 & 0.5 & 29.5 & 14.1 & 0.6 & 23.5 \\
\hline & $8-16$ & 6.3 & 0.4 & 15.7 & 7.7 & 0.3 & 25.7 & 4.8 & 0.3 & 16.0 \\
\hline Bhs & $16-40$ & 5.5 & 0.4 & 13.9 & 2.5 & 0.2 & 12.7 & 2.2 & 0.2 & 11.2 \\
\hline BhsC & $40-80$ & 1.2 & 0.1 & 11.8 & 1.0 & 0.1 & 10.1 & 0.6 & 0.1 & 6.0 \\
\hline C & $>80$ & 0.5 & 0.1 & 4.7 & 0.7 & 0.1 & 7.1 & 0.5 & 0.1 & 4.8 \\
\hline
\end{tabular}

TABLE 4. Selected indicators of acidification of the Podzol soil from the village of Sieraków - area unaffected by fire

\begin{tabular}{|c|c|c|c|c|c|c|c|c|c|c|c|c|c|}
\hline \multirow[t]{3}{*}{ Horizon } & \multirow[t]{3}{*}{$\mathrm{cm}$} & \multicolumn{4}{|l|}{ Term 1} & \multicolumn{4}{|l|}{ Term 2} & \multicolumn{4}{|l|}{ Term 3} \\
\hline & & \multirow[t]{2}{*}{$\overline{\mathrm{pH}} \mathrm{KCL}$} & $\mathrm{Hh}$ & Hex & Alex & \multirow{2}{*}{$\mathrm{pH}_{\mathrm{KCL}}$} & $\mathrm{Hh}$ & Hex & Alex & \multirow[t]{2}{*}{$\mathrm{pH}_{\mathrm{KCL}}$} & \multirow{2}{*}{\multicolumn{3}{|c|}{$\frac{\mathrm{cmol}(+) \cdot \mathrm{kg}^{-1}}{2}$}} \\
\hline & & & $\overline{\mathrm{cmol}(+}$ & $\mathrm{kg}^{-1}$ & & & $\overline{\mathrm{cmol}(+}$ & $\mathrm{kg}^{-1}$ & & & & & \\
\hline $\mathrm{Oh}$ & $3-0$ & 3.14 & 32.37 & 6.06 & 1.75 & 3.44 & 29.95 & 4.34 & 1.81 & 3.30 & 26.82 & 3.81 & 0.92 \\
\hline \multirow[t]{2}{*}{ AEs } & $0-8$ & 3.07 & 11.82 & 5.32 & 1.15 & 3.35 & 9.42 & 5.05 & 1.08 & 3.43 & 6.26 & 3.47 & 0.93 \\
\hline & $8-16$ & 3.51 & 8.15 & 4.73 & 1.12 & 4.33 & 3.74 & 1.23 & 0.48 & 3.81 & 5.69 & 2.41 & 0.69 \\
\hline Bhs & $16-35$ & 4.20 & 4.59 & 1.55 & 0.78 & 4.40 & 2.09 & 0.86 & 0.30 & 4.21 & 3.72 & 1.21 & 0.26 \\
\hline $\mathrm{BhsC}$ & $35-60$ & 4.34 & 2.34 & 0.89 & 0.42 & 4.62 & 1.34 & 2.36 & 0.12 & 4.22 & 1.98 & 0.80 & 0.21 \\
\hline $\mathrm{C}$ & $>60$ & 4.79 & 1.32 & 0.45 & 0.23 & 4.51 & 1.14 & 0.51 & 0.07 & 4.35 & 1.55 & 0.76 & 0.19 \\
\hline
\end{tabular}

In the Oh horizon, the total nitrogen content immediately after the fire was $6.7 \mathrm{~g} \cdot \mathrm{kg}^{-1}$, which was approx. $50 \%$ of the content obtained in the soil taken from the control area. The loss of nitrogen from the soil caused by the fire was smaller than that of carbon. This is in line with the data published by, among others, Caldwell et al. (2002), Bormann et al. (2008) and Francos et al. (2018).

Measurements performed 6 months and a year after the fire indicate that the organic carbon content in the Oh horizon increased in relation to its concentration in the detritus subhorizon (Oe). However, one year after the fire, its concentration is still lower than in the Oe horizon. Total nitrogen content was lower compared with the values obtained immediately after the fire. At the third sampling time, however, an increase was recorded in the total nitrogen content of the soil on the site of the fire.

The research Yildiz et al. (2010) and Dzwonko et al. (2015) confirm that the action of fire reduces the $\mathrm{TN}$ and TOC contents in the organic soil layer. The losses recorded by them amount to $30-80 \%$ for carbon, and from a few to several dozen percent for nitrogen.

As a result of the fire, the $\mathrm{C} / \mathrm{N}$ ratio decreased by almost half in relation to the control and amounted to 10.6 (Table 3). With time, the value of $\mathrm{C} / \mathrm{N}$ in the post-fire soil increased and a year after the fire was 14.8 .
The fire had significantly modified the soil $\mathrm{pH}$. The largest $\mathrm{pH}$ changes were observed immediately after the fire in the top layer of the soil. In the $\mathrm{Oh}$ horizon, the $\mathrm{pH}$ value was significantly higher than in the corresponding layer of the control soil. Measurements made on the subsequent dates indicate a dynamic nature of the changes. With the passage of time, the $\mathrm{pH}$ value in the ashes layer decreased from 4.67 to 3.41 (Table 5). Similar trends were observed by Bogacz et al. (2011), who showed that the increase in soil $\mathrm{pH}$ after a fire is of a short-term nature.

In the Oe horizon of the control soil, the value of hydrolytic acidity $(\mathrm{Hh})$ ranged from 32.37 $\mathrm{cmol}(+) \cdot \mathrm{kg}^{-1}$ on the first sampling date to 26.82 $\mathrm{cmol}(+) \cdot \mathrm{kg}^{-1}$ a year after the fire (Table 4).

As a result of the fire, the hydrolytic acidity of the organic soil horizon was reduced considerably. Immediately after the fire, it was $7.20 \mathrm{cmol}(+) \cdot \mathrm{kg}^{-1}$ (Table 5), which was less than a quarter of that in the control area. On the second and third test dates, the $\mathrm{Hh}$ value was found to have slowly increased (Table 5). The value of exchangeable acidity (Hex) during the study period was subject to significant changes. In the post-fire soil (in the Oh horizon), the $\mathrm{Hw}$ value recorded on the first test date was $0.44 \mathrm{cmol}(+) \cdot \mathrm{kg}^{-1}$ (Table 5), which was almost $1 / 14$ th of the value determined in the control soil. Over the research period, the value of Hex acidity gradually increased, and a year after the fire was $2.89 \mathrm{cmol}(+) \cdot \mathrm{kg}^{-1}$. 
TABLE 5. Selected indicators of acidification of the Podzol soil from the village of Sieraków - area affected by fire

\begin{tabular}{|c|c|c|c|c|c|c|c|c|c|c|c|c|c|}
\hline \multirow[t]{3}{*}{ Horizon } & \multirow[t]{3}{*}{$\mathrm{cm}$} & \multicolumn{4}{|l|}{ Term 1} & \multicolumn{4}{|l|}{ Term 2} & \multicolumn{4}{|l|}{ Term 3} \\
\hline & & \multirow[t]{2}{*}{$\mathrm{pH}_{\mathrm{KCL}}$} & $\mathrm{Hh}$ & Hex & Alex & \multirow[t]{2}{*}{$\mathrm{pH}_{\mathrm{KCL}}$} & $\mathrm{Hh}$ & Hex & Alex & \multirow[t]{2}{*}{$\mathrm{pH}_{\mathrm{KCL}}$} & $\mathrm{Hh}$ & Hex & Alex \\
\hline & & & $\overline{\mathrm{cmol}}$ & $\mathrm{kg}^{-1}$ & & & $\overline{\operatorname{cmol}(}$ & $\mathrm{kg}^{-1}$ & & & \multicolumn{3}{|c|}{$\mathrm{cmol}(+) \cdot \mathrm{kg}^{-1}$} \\
\hline$\overline{\mathrm{Oh}}$ & $2-0$ & 4.67 & 7.20 & 0.44 & 0.02 & 4.07 & 8.24 & 1.86 & 0.26 & 3.41 & 10.65 & 2.89 & 0.37 \\
\hline \multirow[t]{2}{*}{$\overline{\mathrm{AEs}}$} & $0-8$ & 3.08 & 9.36 & 4.21 & 1.68 & 3.25 & 7.53 & 6.12 & 1.07 & 3.33 & 7.07 & 3.38 & 0.83 \\
\hline & $8-16$ & 3.36 & 8.28 & 4.34 & 1.75 & 4.24 & 4.37 & 2.09 & 0.75 & 4.16 & 3.72 & 1.08 & 0.28 \\
\hline Bhs & $16-40$ & 4.22 & 3.81 & 1.41 & 0.66 & 4.31 & 2.25 & 1.07 & 0.46 & 4.23 & 3.65 & 0.96 & 0.19 \\
\hline $\mathrm{BhsC}$ & $40-80$ & 4.30 & 1.82 & 0.95 & 0.41 & 4.33 & 1.58 & 0.93 & 0.39 & 4.37 & 1.35 & 0.66 & 0.15 \\
\hline$\overline{\mathrm{C}}$ & $>80$ & 4.49 & 1.11 & 1.75 & 0.22 & 4.36 & 1.49 & 0.88 & 0.25 & 4.36 & 1.34 & 0.48 & 0.12 \\
\hline
\end{tabular}

In the fire-affected area, a very considerable reduction was found in the $\mathrm{Al}_{\text {ex }}$ content in the organic layer. Immediately after the fire, the exchangeable aluminum content was $0.02 \mathrm{cmol}(+) \cdot \mathrm{kg}^{-1}$ and was significantly lower in relation to the content in the control soil, in which it was $1.75 \mathrm{cmol}(+) \cdot \mathrm{kg}^{-1}$. On subsequent test dates, the exchangeable aluminium content in the Oh horizon was found to have steadily increased, and a year after the fire the $\mathrm{Al}_{\mathrm{ex}}$ content was $0.37 \mathrm{cmol}(+) \cdot \mathrm{kg}^{-1}$.

The research results presented in this paper indicate that fire has a significant influence on reducing soil acidity. The changes mainly affect the top layer, with mineral horizons being affected to a lesser extent. This statement is also reflected in the literature data (Boerner et al. 2009, Prędecka 2009, Tufeccioglu et al. 2010, Aref et al. 2011).

\section{CONCLUSIONS}

1. The surface fire of pine forest, in the fresh coniferous forest habitat can lead to strong degradation by reducing the TOC and TN content in the soil.

2. The fire has a deacidifying effect on the top soil layer causing the increase of $\mathrm{pH}$, reduction of hydrolytic and exchangeable acidity and reduction of exchangeable aluminum content.

3. The fire-induced changes in soil properties affect mainly the top layer, with deeper mineral horizons being affected to a lesser extent.

\section{REFERENCES}

Alcañiz M., Outeiro L., Francos M., Farguell J., Úbeda X., 2016. Long-term dynamics of soil chemical properties after a prescribed fire in a Mediterranean forest (Montgrí Massif, Catalonia, Spain). Science of the Total Environment 572: 13291335.

Aref I.M., Atta H.A., Ghamade A.R., 2011. Effect of forest fires on tree diversity and some soil properties. International Journal of Agriculture and Biology 13: 659-664.
Badía D., López-García S., Martí C., Ortíz-Perpiñá O., GironaGarcía A., Casanova-Gascón J., 2017. Burn effects on soil properties associated to heat transfer under contrasting moisture content. Science of the Total Environment 601-602: 1119-1128.

Bartkowiak A., Lemanowicz J., 2017. Effect of forest fire on changes in the content of total and available forms of selected heavy metals and catalase activity in soil. Soil Science Annual 68(3): 140-148.

Boerner R.E.C., Hart S., Huang J., 2009. Impacts of Fire and Fire Surrogate treatments. Journal of Applied Ecology 19(2): 338-358.

Bogacz A., Jędo M., Woźniczka P., 2011. Właściwości silnie przesuszonych organicznych gleb popożarowych obiektu Sobin Jędrzychów. Woda-Środowisko-Obszary Wiejskie 11, 4(36): 43-56.

Bojarski K., Kaczmarek Z., 2018. Soil properties and dendrological parameters of trees after 20-year reforestation in the post fire area Potrzebowice (middle Poland). Journal of Research and Applications in Agricultural Engineering 63(2): 9-18.

Bormann B., Homann P., Dabyshire R.L., Morrissette B.A., 2008: Intense forest wildfire Sharpy reduces mineral soil $\mathrm{C}$ and $\mathrm{N}$ : the first direct evidence. Canadian Journal of Research 38: 2771-2783.

Caldwell T.G., Johnson D.W., Miller W.W., 2002. Forest floor carbon and nitrogen loss due to prescribed fire. Soil Science Society of America Journal 66: 262-267.

Dzwonko Z., Loster S., Gawroński S., 2015. Impact of fire severity on soil properties and the development of tree and shrub species in a Scots pine moist forest site in southern Poland. Forest Ecology and Management 342: 56-63.

Francos M., Úbeda X., Pereira P., Alcańiz M., 2018. Long-term impact of wildfire on soils exposed to different fire severities. A case study in Cadiretes Massif (NE Iberian Peninsula). Science of the Total Environment 615: 664-671.

Gonet S.S., 2010. Wpływ pożaru lasu na właściwości materii organicznej gleb [W:] Środowiskowe skutki pożaru lasu (red. Sewerniak P., Gonet S.S.), PTSH, Wrocław: 51-81.

Hewelke E., Lidia Oktaba L., Gozdowski D., Kondras M., Olejniczak I., Górska E.B., 2018. Intensity and Persistence of Soil Water Repellency in Pine Forest Soil in a Temperate Continental Climate under Drought Conditions. Water 10: 1121, doi:10.3390/w10091121.

Hubbert R.K., Wohlgemuth P.M., Beyers J.L., Narog M.G., Ross 
G., 2012. Post-fire soil water repellency, hydrologic response, and sediment yield compared between grass-converted and chaparral watersheds. Fire Ecology Journal 2: 143-162.

IUSS Working Group WRB, 2015. World Reference Base for Soil Resources 2014, update 2015. International soil classification system for naming soils and creating legends for soil maps. World Soil Resources Reports No. 106. FAO, Rome.

Januszek K., Lasota J., Gruba P., Domicz G., 2001. Właściwości fizyczno-chemiczne i biochemiczne gleb bielicowych sześć lat po pożarze całkowitym lasu. Acta Agraria et Silvestria 39: 47-61.

Prędecka A., 2009. Wpływ pożarów lasów na biomasę, dynamikę rozwoju wybranych grup mikroflory, mikro- i mezofauny oraz aktywność dehydrogenazy w glebie. Praca doktorska na Wydziale Rolnictwa i Biologii, SGGW.

Sawicki T., 2004. Prawo w dżungli. Przegląd Pożarniczy 7: 33-34. Szczygieł R., 2012. Wielkoobszarowe pożary lasów w Polsce. Bezpieczeństwo i Technika Pożarnicza 2012/1, CNBO: 67-78.

Szczygieł R., Piwnicki J., 2012. Pożary lasu w 2011 roku. Stan uszkodzenia lasów w Polsce w 2011 roku na podstawie badań monitoringowych. Instytut Badawczy Leśnictwa, Sękocin Stary: 85-87.

Tufeccioglu A., Kucuk M., Bilgili E., 2010. Soil properties and root biomass responses to prescribed burning in young corsican pine (Pinus nigra Arn.) stands. Journal of Environmental Biology 31: 369-373.

Ubysz B., Szczygieł R., 2005. Straty na lata. Przegląd Pożarniczy 7: 18-19.

Website 1: http://effis.jrc.ec.europa.eu/reports-and-publications/ annual-fire-reports.

Website 2: http://www.lasy.gov.pl.

Yildiz O., Esen D., Sarginci M., Toprak B., 2010. Effects of forest fire on soil nutrients in Turkish pine Ecosystems. Journal of Environmental Biology 31: 11-13.

Received: January 11, 2019

Accepted: April 2, 2019

Associated editor: t. Uzarowicz

\section{Wpływ pożaru na wybrane właściwości fizykochemiczne gleby leśnej}

Streszczenie: Celem przeprowadzonych badań było określenie, czy i na ile pożar powierzchniowy obszarów leśnych determinuje zmiany właściwości fizycznych i chemicznych gleby. Materiał do badań stanowiły próbki gleby pobrane z profili glebowych z obszaru wypalonego oraz nie objętego pożarem. W próbkach gleby oznaczono zawartość węgla organicznego i azotu ogółem oraz wybrane wskaźniki zakwaszenia gleby (pH, kwasowość hydrolityczną i wymienna). Pożar spowodował znaczną degradację glebowej materii organicznej przejawiającą się zmniejszeniem zawartości w glebie węgla organicznego (o ponad 75\%) i azotu ogólnego (o $50 \%$ ). Negatywnym skutkiem powstałych zmian było również zawężenie stosunku C/N, a pozytywnym wzrost wartości $\mathrm{pH}$ gleby (od 3,14 do 4,67) oraz kilkukrotne zmniejszenie kwasowości hydrolitycznej i wymiennej.

Słowa kluczowe: pożar, lasy, właściwości gleby, węgiel organiczny 